Article

\title{
Technical and economic aspects of Stone Pine (Pinus pinea L.) maintenance in urban environments
}

\author{
Marcello Biocca*, Pietro Gallo and Giulio Sperandio \\ CREA Consiglio per la ricerca in agricoltura e l'analisi dell'economia agraria. Centro di ricerca Ingegneria e \\ Trasformazioni agroalimentari, via della Pascolare 16, 00015 - Monterotondo (Roma). \\ * Correspondence: marcello.biocca@crea.gov.it
}

\begin{abstract}
The Italian Stone Pine (Pinus pinea L.) is one of the most employed ornamental trees in towns with Mediterranean climates. For example, in the city of Rome, Pinus is the most common genus, with more than 51,000 trees. This study investigates technical and economic features of maintenance operations of Stone Pines and evaluates the productivity and costs of the observed yards. Pruning and felling are the most frequent management operations of trees in towns and this study analyzes the features of these operations carried out in 14 work sites. The operations were carried out either with aerial platforms (19 trees) or ascending the crown by tree-climbing (6 trees). The operations were sampled with time studies (12 trees for pruning and 13 for felling). Work time was measured from the beginning of operations to the transport of the residual biomass to the collection and loading point, using centesimal stopwatches and video recording. The total residual biomass was weighed or assessed. Total observation time amounted to 63.1 hours. The evaluation of the costs of each work site considered the fixed and the variable costs and the costs for the labor force. A Multiple Linear Regression model (statistics: determination coefficient $\mathrm{R}^{2}$ : 0.74 , adjusted $\mathrm{R}^{2}$ : 0.67 , p-value $<0.001$ ) which utilizes four regressors easily evaluable before the work, was adopted to predict the gross time of the operations. This paper can contribute to optimize trees maintenance methods in urban sites and to assess the potential residual wood biomass attainable from urban forestry maintenance in the city of Rome.
\end{abstract}

Keywords: urban forestry; work analysis; residual biomass; pruning costs.

\section{Introduction}

The Italian Stone Pine, or Umbrella Pine (Pinus pinea L.) is both a landmark of the Mediterranean coastal areas and an ornamental tree widely used in parks, streets and gardens [1]. For example, according to the data of Rome municipality, in the city of Rome (Italy) Pinus is the most common genus, with more than 51,000 trees, corresponding to $16.4 \%$ of the total registered trees [2].

With its distinguishing crown shape, Stone Pine contributes to make unique and pictorial the skyline of the city. This species was been widely planted especially between the 20s and 50s of the last century [3], so that a great number of trees are now old or senescent. Various other issues bother this species in town, like the threats deriving from climate change [4], which undermine the static stability of plants and incite decline [5-7], from new pests and pathogens, such as Toumeyella parvicornis and Heterobasidion spp. [8-10], from mismanagement (especially road maintenance and management of underground facilities) [11]. Moreover, also pinewoods represent environmental amenity areas at risk, being under siege from intensive urbanization [12]. In this framework the care of pines is very urgent and complex, and a professional approach is needed to manage and maintain trees in towns as well as to protect workers and residents during all phases of these work sites. Due to the above-mentioned reasons, the maintenance of this species may constitute a serious issue for the owners.

Pruning and felling are the most frequent management operations of trees in towns. Pruning is performed throughout the lifetime of an urban tree for various reasons, including: improving growth 
form, alleviating structural problems (such as removal of deadwood), crown raising, managing pests or diseases, decreasing failure risks and resolving conflicts with infrastructures (buildings, electric cables, road signs and lights, etc.) [13]. An ideal pruning should be operated reducing to a minimum the quantity of removed crown, to safeguard the photosynthetic apparatus of the plant and to reduce the operative costs [14]. Stone Pines need to be ordinary pruned principally to remove the lower branches that naturally tend to dry and fall and to eliminate died wood in the crown. Sometimes, heavier cuts are necessary to equilibrate crowns that are assessed as source of failure risks [15]. Felling of senescent, died or hazard trees has increased in the last years for the reasons mentioned above.

Pruning and felling operations can be carried out either utilizing an aerial lift or ascending the crown with ropes, commonly named "tree-climbing". The choice of the employed method largely depends on the accessibility of the tree. Tree-climbing is preferred when targeted and selective interventions on tree branches is demanded and where trees are in confined areas where machinery cannot enter. In urban forestry, tree-climbing is often the only possible solution to maintain trees. The scientific literature about the maintenance operation performed on urban trees by professional arborists seems rather poor. Safety aspects of the method [16-18], technical approaches [19] and economic aspects [20] were instead more extensively studied.

An additional interesting theme related to the maintenance of urban trees is the utilization of the residual biomass, a potentially large and underutilized resource that could exploited at local level for wood products and bio-based fuels for power and heat generation, after the volume has been reduced by chipping [21-26]. It is also worth noticing that the possibility to reutilize the residuals allows the tree owner to save the disposal charge usually payed (around $80 € \mathrm{Mg}^{-1}$ ).

The purposes of this study are: (1) investigating technical and economic features of felling and pruning of Stone Pines in urban environment, (2) evaluating the productivity and costs of the observed yards and (3) assessing the potential residual biomass.

\section{Material and Methods}

This study analyzes works carried out in 14 work sites (with a total of 25 trees observed). The operations were carried out either with aerial platforms (19 trees) or ascending the crown by treeclimbing (6 trees). The felling operations involved 13 trees (observed in 9 yards) (Table 1) and the pruning operations 12 trees (observed in 5 yards) (Table 2). In total, 13 work sites were in gardens and parks and one was a tree-lined along a public road. Trunk diameters and heights of trees were measured by means of a tree diameter tape and by a laser rangefinder (mod. TruPulse 360R, Laser Technology Inc), respectively. The form and the size of the crown were evaluated by measuring its projection on the soil.

The yards showed differences of accessibility and in the ease of carrying out the work. For this aspect, a synthetic qualitative variable named "target", ranging from 1 to 5 , was specifically created. This descriptor indicates the work easiness, especially in relation to the yard's location. A work site scoring " 1 " means that the tree is located close to a busy road, all the big logs must be secured with a rope for their descent, etc. The distance of the trees to the loading point of residual biomass ranged from $1 \mathrm{~m}$ (full accessibility, with the possibility to place a truck for loading very close to the tree) to $40 \mathrm{~m}$ (the collected biomass must be manually transported from the tree to the collection point).

Work time was measured for every operation carried out by a worker during his activity. In particular, five main elements were identified and separated: (1) "setting and stacking" (which includes yard's preparation, time to wear personal protective equipment, transport to the collection point and stacking of residual wood, cleaning of the site), (2) "cutting", (time during the operator is using either manual or motorized tools to cut branches or trunk), (3) "shift" (movement of the operator inside the crown, by either ascending the crown by ropes or moving the platform), (4) "delay time for avoidable time losses", (5) "delay time for unavoidable time losses" [27-28]. Delays include mechanical delays, (breakdowns, tools replacement, all maintenance outside the standard preparation and so on); operator delays (rest, breaks, physiological, smoke, phone calls), and organizational and other delays, including waiting for the platform, interference, reconnaissance and 
planning, refuel. In this study the time (and the cost) for loading and transportation of the obtained biomass is not considered. The time elements were recorded by the same researcher using centesimal stopwatches and video recording. Total observation time amounted to 63.1 hours.

In the case of tree removal, all the operations were carried out by dismantling the tree. The trunk was cut up into pieces and the operator calculated the length of each piece based on diameter and weight.

Five private companies carried out the works, operating both with their own equipment and with rental aerial lifts. All the companies were formed by experienced professional arborists. The residual biomass was either assessed by measuring the volume of cut branches stacked at the collection point or weighing the wood with a hanging electronic weighing scale (Laumas, mod. Dten. 500/1). The volume data were converted in fresh weights according to conversion tables [29].

Four values were provided to summarize the data analyses: (1) gross time, i.e. the total time of work carried out per each tree ( $\mathrm{h}$ tree-1); (2) biomass productivity, i.e. the estimated or measured fresh weight of residual obtained biomass $\left(\mathrm{Mg} \mathrm{h}^{-1}\right)$; (3) hourly cost, i.e. the total cost per hour of work $\left(€ \mathrm{~h}^{-1}\right)$; (4) cost per tree, the total cost of work per each tree ( $€$ tree-1). These variables, the dendrometric data of 19 trees and the site characteristics shown in Table 1 and 2 constituted the base of data analysis.

The evaluation of the operating costs of each work yard was carried out by means of an analytical method, considering the fixed costs, the variable costs and the costs for the labor force [30]. A Multiple Linear Regression (MLR) modelling was adopted to predict the gross time per tree ( $\mathrm{h}$ tree-1). MLR is one of the most broadly applied methods for the estimation of forest structure variables. MLR is a linear approach for modeling the relationship between a scalar dependent variable, the gross time per tree in this case, and two or more explanatory variables. The variables that improve goodness of fit were selected and included in the model. The predicting capacity of the equation is described by the coefficient of determination $\left(\mathrm{R}^{2}\right)$ and the independent variables were included in the model when the $p$-value is $<0.05$. The value 0 or 1 respectively for the absence or the presence of the specific treatment was used [31]. The statistical analysis of the MLR was performed with the software SPSS [32]. Since the working times data resulted non-normally distributed, to assess the differences among work systems and type of operations, the Kruskal-Wallis nonparametric rank test was performed with the software R [33].

\section{Results}

Dendrometric data of trees and main characteristics of studied yards were collected during the study, for felling and pruning yards (Table 1 and 2, respectively). Regarding the growth stage, all trees were mature, with the diameter at $1.3 \mathrm{~m}$ ranging from to 42 to $100 \mathrm{~cm}$ and the height from 11 to $27 \mathrm{~m}$. 
Table 1. Characteristics and results for observed trees in felling yards ( $\mathrm{AL}=$ aerial lift; $\mathrm{TC}=$ treeclimbing; D.b.h. = diameter at $1.3 \mathrm{~m}$ from the ground level).

\begin{tabular}{|c|c|c|c|c|c|c|c|c|c|c|c|}
\hline Yard & $\begin{array}{l}\text { Syst } \\
\text { em }\end{array}$ & $\begin{array}{c}\text { Heig } \\
\text { ht }\end{array}$ & $\begin{array}{c}\text { D.b. } \\
\text { h. }\end{array}$ & $\begin{array}{l}\text { Crown } \\
\text { diameter }\end{array}$ & $\begin{array}{c}\text { Observed } \\
\text { trees }\end{array}$ & $\begin{array}{l}\text { Gross } \\
\text { time }\end{array}$ & $\begin{array}{c}\text { Obtained } \\
\text { biomass } \\
\text { per tree }\end{array}$ & $\begin{array}{c}\text { Producti } \\
\text { vity }\end{array}$ & $\begin{array}{c}\text { Unitary } \\
\text { time }\end{array}$ & $\begin{array}{c}\text { Hourly } \\
\text { cost }\end{array}$ & $\begin{array}{c}\text { Cost per } \\
\text { tree }\end{array}$ \\
\hline & & $(\mathrm{m})$ & $(\mathrm{cm})$ & (m) & N. & h tree t $^{-1}$ & Mg tree ${ }^{-1}$ & $\mathrm{Mg} \mathrm{h}^{-1}$ & $\mathrm{~h}$ tree $^{-1}$ & $€ \mathrm{~h}^{-1}$ & $€$ tree $^{-1}$ \\
\hline FAN & $\mathrm{AL}$ & 20 & 65 & 10 & 3 & 0.74 & 1.60 & 2.18 & 0.46 & 118.3 & 29.0 \\
\hline AA1 & $\mathrm{AL}$ & 27 & 100 & 15 & 1 & 8.08 & 15.00 & 1.86 & 0.54 & 107.9 & 870.9 \\
\hline AA2 & $\mathrm{AL}$ & 25 & 99 & 12 & 1 & 5.88 & 14.00 & 2.38 & 0.42 & 157.4 & 925.9 \\
\hline \multirow{3}{*}{ ITA } & & 19.9 & 81 & 9 & 1 & 0.80 & 3.10 & 3.87 & 0.26 & 62.7 & 50.2 \\
\hline & $\mathrm{AL}$ & 19.4 & 66 & 11 & 1 & 1.92 & 4.53 & 2.35 & 0.43 & 62.7 & 120.6 \\
\hline & & 18 & 67 & 8 & 1 & 2.58 & 4.98 & 1.93 & 0.52 & 62.7 & 161.7 \\
\hline BUS & $\mathrm{AL}$ & 22 & 67 & 12 & 1 & 8.25 & 5.40 & 0.65 & 1.53 & 77.1 & 635.8 \\
\hline PIG & $\mathrm{TC}$ & 15 & 60 & 9 & 1 & 3.46 & 1.40 & 0.40 & 2.47 & 97.7 & 337.9 \\
\hline CLS & $\mathrm{TC}$ & 15 & 42 & 7 & 1 & 1.88 & 0.80 & 0.42 & 2.35 & 37.0 & 69.6 \\
\hline LEM & $\mathrm{TC}$ & 11 & 49 & 7 & 1 & 2.79 & 1.57 & 0.56 & 1.78 & 59.5 & 166.0 \\
\hline ANA & $\mathrm{TC}$ & 16 & 80 & 11 & 1 & 5.50 & 4.20 & 0.76 & 1.31 & 44.5 & 245.1 \\
\hline \multicolumn{12}{|l|}{ Aver } \\
\hline age & & 18.9 & 71 & 10 & 1.2 & 3.8 & 5.1 & 1.6 & 1.1 & 80.7 & 328.4 \\
\hline
\end{tabular}

Table 2. Characteristics and results for observed trees in pruning yards ( $\mathrm{AL}=$ aerial lift; $\mathrm{TC}=$ treeclimbing; D.b.h. = diameter at $1.3 \mathrm{~m}$ from the ground level).

\begin{tabular}{|c|c|c|c|c|c|c|c|c|c|c|c|}
\hline \multirow[t]{2}{*}{ Yard } & \multirow[t]{2}{*}{$\begin{array}{c}\text { Syste } \\
\text { m }\end{array}$} & $\begin{array}{c}\text { Heig } \\
\text { ht }\end{array}$ & $\begin{array}{l}\text { D.b. } \\
\text { h. }\end{array}$ & $\begin{array}{c}\text { Crown } \\
\text { diamet } \\
\text { er }\end{array}$ & $\begin{array}{c}\text { Observed } \\
\text { trees }\end{array}$ & $\begin{array}{l}\text { Gross } \\
\text { time }\end{array}$ & $\begin{array}{c}\text { Obtained } \\
\text { biomass } \\
\text { per tree }\end{array}$ & $\begin{array}{c}\text { Producti } \\
\text { vity }\end{array}$ & $\begin{array}{c}\text { Unitary } \\
\text { time }\end{array}$ & $\begin{array}{c}\text { Hourly } \\
\text { Cost }\end{array}$ & $\begin{array}{c}\text { Cost per } \\
\text { tree }\end{array}$ \\
\hline & & $(\mathrm{m})$ & $(\mathrm{cm})$ & $(\mathrm{m})$ & N. & $h$ tree $^{-1}$ & Mg tree ${ }^{-1}$ & $\mathrm{Mg} \mathrm{h}^{-1}$ & h tree-1 & $€ \mathbf{h}^{-1}$ & $€$ tree $^{-1}$ \\
\hline LAT & $\mathrm{AL}$ & 16 & 72 & 14 & 5 & 1.03 & 2.10 & 2.03 & 0.49 & 86.2 & 17.8 \\
\hline \multirow{4}{*}{ ITP } & \multirow{4}{*}{$\mathrm{AL}$} & 19 & 67 & 11 & 1 & 0.86 & 0.29 & 0.34 & 2.96 & 52.8 & 45.4 \\
\hline & & 21 & 60 & 10 & 1 & 0.97 & 0.33 & 0.34 & 2.94 & 52.8 & 51.1 \\
\hline & & 19.5 & 66 & 10 & 1 & 1.13 & 0.38 & 0.34 & 2.98 & 52.8 & 59.7 \\
\hline & & 17.2 & 57 & 9 & 1 & 1.60 & 0.43 & 0.27 & 3.71 & 52.8 & 84.1 \\
\hline ENE & $\mathrm{AL}$ & 19.8 & 79 & 14 & 1 & 3.28 & 1.44 & 0.44 & 2.27 & 54.6 & 178.9 \\
\hline INF & $\mathrm{TC}$ & 15.4 & 74 & 12 & 1 & 3.19 & 0.90 & 0.28 & 3.55 & 46.7 & 149.1 \\
\hline MAG & $\mathrm{TC}$ & 22 & 70 & 13 & 1 & 3.56 & 1.00 & 0.28 & 3.56 & 36.7 & 130.6 \\
\hline \multicolumn{12}{|l|}{ Avera } \\
\hline ge & & 18.7 & 68 & 12 & 1.5 & 2.0 & 0.86 & 0.5 & 2.8 & 54.4 & 89.6 \\
\hline
\end{tabular}

The working times of the different work elements of the observed felling and pruning yards are summarized in Figure 1. In general, the yards of felling take around the double time of the pruning ones (4.2 and $2.4 \mathrm{~h}_{\text {tree }}{ }^{-1}$, respectively), resulting statistically significant $(\mathrm{p}<0.001)$ after the KruskalWallis test. The cutting operation (both in pruning and felling) is the main work time (about $32 \%$ of total work time). Setting and stacking times are greater operating in tree-climbing (average 26.5\%) 
than with aerial lift (average 17.5\%). However, no significant difference was showed comparing the gross operation time between felling and pruning operations ( $\mathrm{p}$-value $=0.6692)$.

Regarding the avoidable delay time, the tree-climbing shows an average of $2.5 \%$ while aerial lift reaches an average of $16.5 \%$.

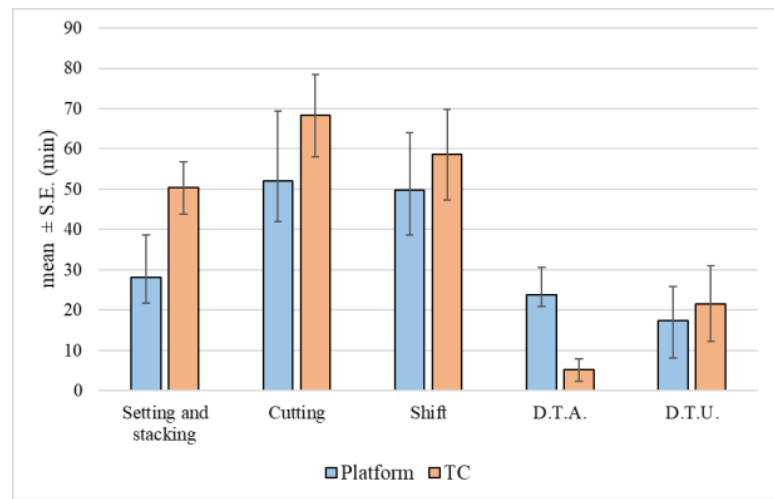

(a)

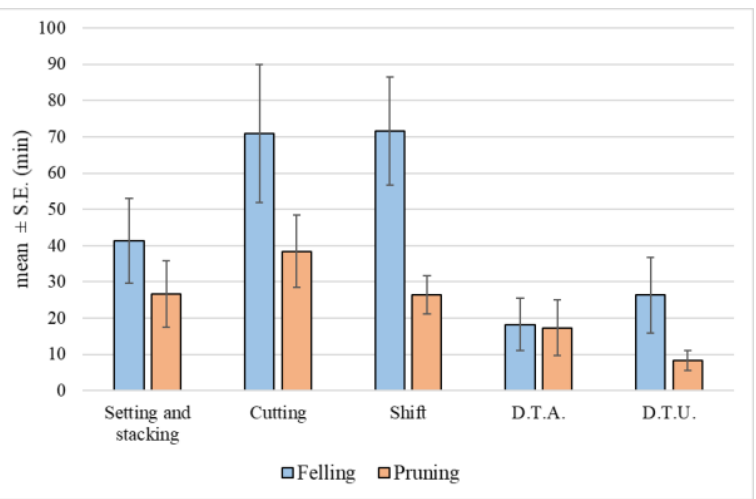

(b)

Figure 1. Total working operation times ( $\mathrm{min} \pm$ standard error), (a) by the operating method $(\mathrm{TC}=$ tree climbing; Platform = aerial platform) and by (b) cultural operation (D.T.A = delay time avoidable; D.T.U. = delay time unavoidable).

The values of gross time $\left(\mathrm{h}\right.$ tree-1), residual biomass productivity $\left(\mathrm{Mg} \mathrm{h}^{-1}\right)$, hourly cost $\left(€ \mathrm{~h}^{-1}\right)$ and cost per tree $\left(€\right.$ tree $\left.^{-1}\right)$, per each combination of work system (aerial lift and tree-climbing) and type of operation (felling and pruning) are shown in Figure 2. Obviously, the results are different comparing felling yards with pruning yards. For example, using the aerial lift, the cost per tree of felling is more than six time greater than the cost for pruning (515 and $86 €$ tree $^{-1}$, respectively).

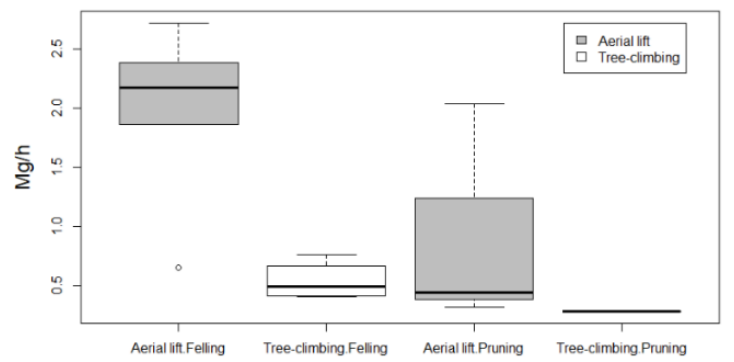

(a)

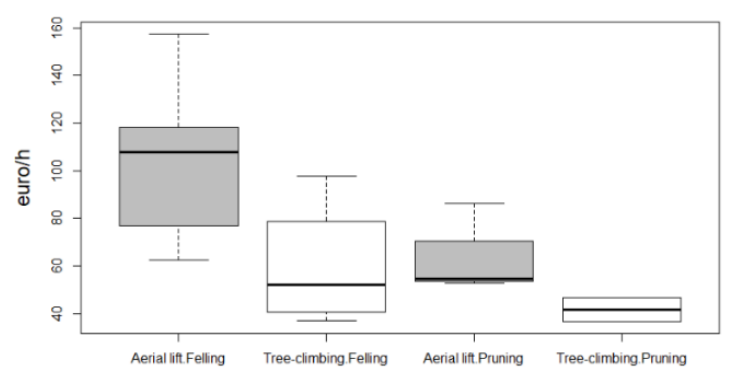

(c)

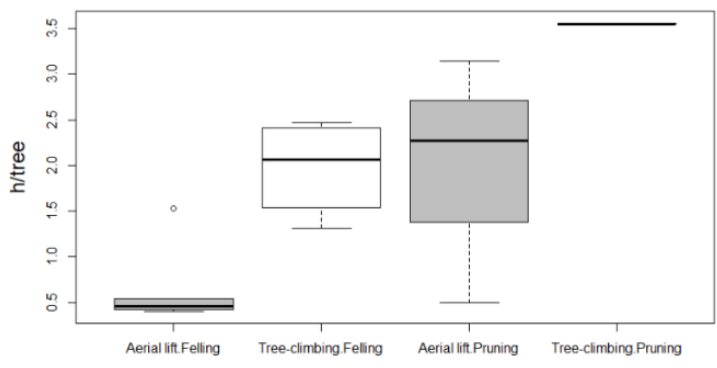

(b)

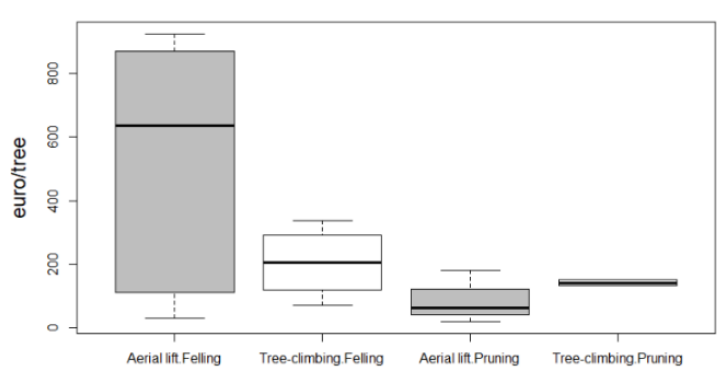

(d)

Figure 2. Distribution values of systems by work operations in the 14 observed yards. (a) Productivity $\left(\mathrm{Mg} \mathrm{h}^{-1}\right)$; (b) gross time (h tree $\left.{ }^{-1}\right)$; (c) hourly cost $\left(€ \mathrm{~h}^{-1}\right)$; (d) unitary cost $\left(€\right.$ tree $\left.^{-1}\right)$. Sample size (n): aerial lift by felling: $n=5$; tree-climbing by felling: $n=4$; aerial lift by pruning: $n=3$; tree-climbing by pruning: 
n=2 (box limits represent: 25 and 75 percentiles; line within box: median; whisker ends: minimum and maximum; circles outside the box: outliers).

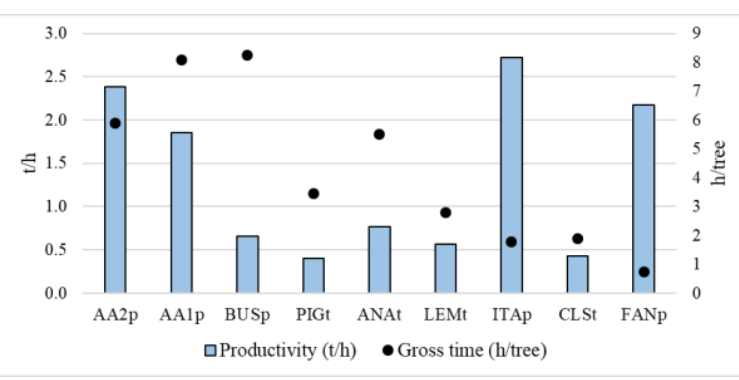

(a)

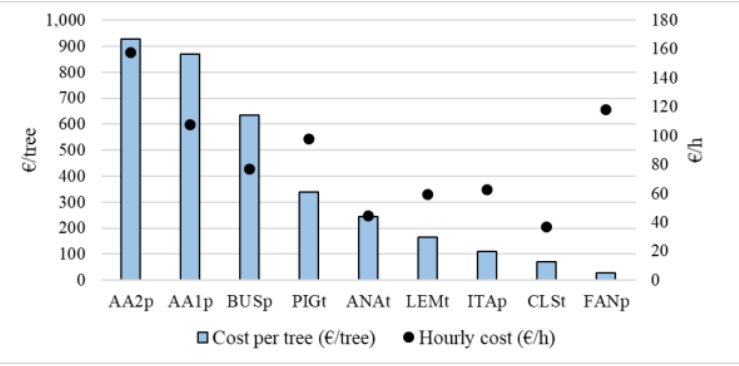

(b)

Figure 3. (a) Unitary time (h tree-1) and productivity $\left(\mathrm{Mg} \mathrm{h}^{-1}\right)$ of the nine felling work yards; (b) cost per tree $\left(€\right.$ tree $\left.\mathrm{e}^{-1}\right)$ and hourly cost $\left(€ \mathrm{~h}^{-1}\right)$ (the subscript " $\mathrm{p}$ " means aerial platforms, the subscript " $\mathrm{t}^{\text {" }}$ means tree-climbing).

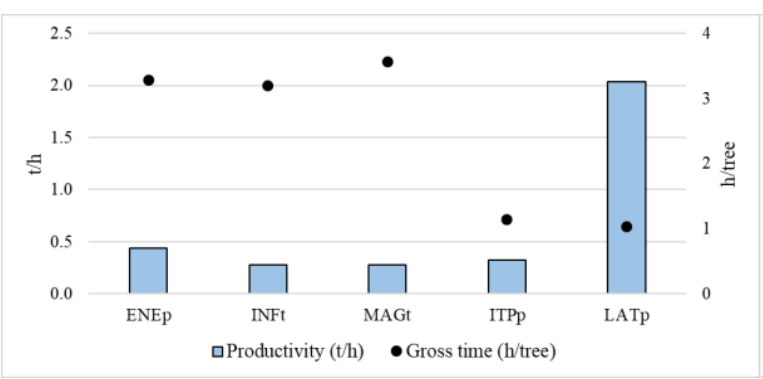

(a)

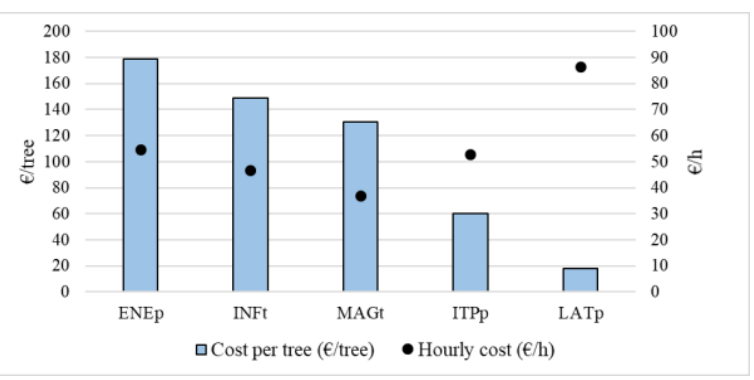

(b)

Figure 4. (a) Unitary time (h tree $\left.{ }^{-1}\right)$ and productivity $\left(\mathrm{Mg} \mathrm{h}^{-1}\right)$ of the five pruning work yards; (b) cost per tree $\left(€\right.$ tree $\left.{ }^{-1}\right)$ and hourly cost $\left(€ \mathrm{~h}^{-1}\right)$ (the subscript " $\mathrm{p}$ " means aerial platforms, the subscript " $\mathrm{t}$ " means tree-climbing).

The Multiple Linear Regression (MLR) model to estimate the gross time per tree $\left(\mathrm{h}\right.$ tree $\left.{ }^{-1}\right)$ showed significant results ( $F$ test $=10.953$; p-value $<0.001$ ) (Fig. 5). The equation of the MLR model adopted to estimate the unitary time (GTt) was the following:

$$
\mathrm{GTt}=-1,195-1,587 \times \text { work }-0,104 \times \text { target }+2,046 \times \text { system }+1,897 \times \text { class }
$$

The regression model individuated four independent regressors to predict the gross time: (1) "work", indicating the performed operation - felling or pruning; (2) "target," a synthetic qualitative variable, ranging from 1 to 5 , indicating the easiness of the work, especially in relation to the location of the yard; (3) "system", which indicates if the work was carried out by aerial lift or by tree-climbing; (5) "class", indicating 5 dimensional classes of the tree as function of the estimated residual tons of residual attainable biomass $(1:<1 ; 2: 1-3 ; 2: 3-5 ; 4: 5-7 ; 5:>7 \mathrm{Mg})$. 


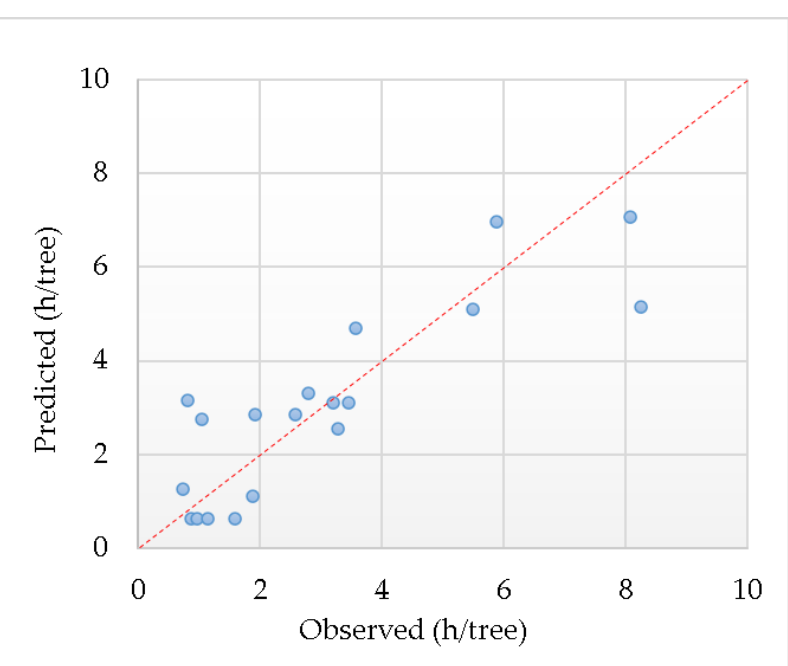

Figure 5. Predicted and observed values of gross time (h tree $\mathrm{e}^{-1}$ ) on 19 analyzed trees (statistics: determination coefficient $R^{2}: 0.74$, adjusted $R^{2}: 0.67$, p-value $<0.001$ ).

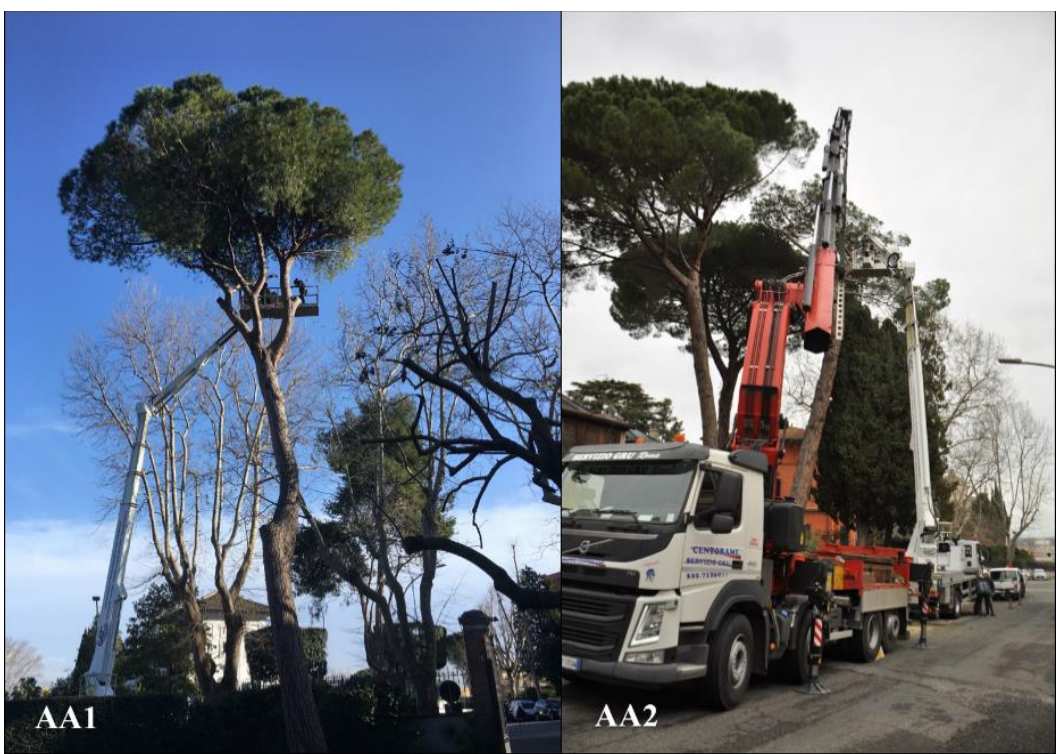

Figure 6. The felling yards AA1 and AA2. Note in the AA2 the truck mounted crane employed to descend the heaviest logs.

The obtained biomass amounted to an average value of 0.86 and $5.10 \mathrm{Mg}^{\text {tree }} \mathrm{e}^{-1}$ for pruning and felling, respectively (Table 1 and 2). These data allow to calculate the potential residual woody biomass obtainable from Pines in the city of Rome. Given the estimated number of Stone Pines of 51,000 [2] and considering a rate of tree yearly mortality of 3\% [34] and a 6-year pruning return time, the obtainable biomass for a city like Rome, can be equal to ca. 7800 and $7450 \mathrm{Mg}^{\text {year-1 }}$ from felling $^{-1}$ and pruning, respectively.

\section{Discussion}

The study was conducted on commercial operations carried out in urban yards. The time work analysis revealed numerous aspects of the technical features of maintenance of Pinus pinea.

As for time work elements it was noted that "setting and stacking" time is greater operating in tree-climbing than with aerial lift. This is due to the time for wearing personal protective equipment, slings, etc. and to the time needed to launch the throwline, which does not always succeed in the first attempt. Moreover, it resulted decisive the difference in terms of distance from the tree and the 
collection point, significantly higher in tree-climbing yards than in the aerial lift ones $(2$ and $18 \mathrm{~m}$, respectively).

Regarding the "avoidable delay time", the tree-climbing shows an average of $2.5 \%$ while aerial lift reaches an average of $16.5 \%$. This is likely due by the limited view of the crown of the lift operator, causing occasionally the platform got stuck in the branches for a while. Moreover, the operator in the aerial lift needs to communicate with the ground workers more often than the tree-climber, in order to place the platform properly. On the contrary, the tree-climber tends to work more autonomously.

The cost per tree of felling is more than six time greater than the cost for pruning. This data is largely influenced by two particular yards (AA1 and AA2) that involved the removal of two very large trees (Fig. 6). However, also these two yards were included in the data set because they represent real cases to complete the wide situations that can be found in urban trees work maintenance.

In this study a regression model individuated four independent regressors to predict the gross time. These variables fit the model and maximizes its goodness. Other variables tested in the model construction (for example the diameter and crown size) were not capable to significatively contribute to the model. It is also worth noticing that the selected variables can be easily estimated before the work.

Regarding the residual biomass, it may represent a potential renewable resource, for example, for energy production. Considering that the potential obtainable biomass amounts to about 15,200 Mg year-1 of fresh wood (45\% of humidity) can supply a plant of about 39,700 MWh. Moreover, the possibility to reutilize the residuals allows the tree owner to save the disposal charge usually payed.

\section{Conclusions}

In the present study, urban trees yards of felling and pruning were studied. The research has regarded a species, Pinus pinea, that is extensively utilized as ornamental tree in cities and that has been threatened by several causes. A work time analysis was carried out from the setting of the yards to the preparation for the loading of the residual wood. Time analysis can individuate weakness points in the operations, and it contributes to study the work from a safety point of view. In the observed cases, the gross time is slightly higher when the operations are carried out by tree-climbing, both in pruning and felling (Figure 2). This seems due mainly to the "setting and stacking" operation time (Figure 1) that is generally higher for tree-climbers. Since this time element includes several operations, (preparation of the yard, dressing of the operator, preparation to ascend, transport of the cut wood to the collection and its stacking), many factors can cause the observed difference. However, it was shown that, in the case of tree-climber, the initial phases of the work are longer than the case with aerial lift. Moreover, since the location of tree-climber sites of work is more problematic than those of the places where an aerial lift can operate, it resulted crucial the distance from the tree and the collection point, significantly higher in tree-climbing yards than in the aerial lift ones ( 2 and $18 \mathrm{~m}$ in average, respectively). Consequently, the organization of the yard should take in account the distance from the tree to the point where the wood is stacked before the loading, and the firm should take decisions to optimize this point.

The potential residual wood biomass attainable from Stone Pines maintenance was merely estimated, basing the study on the registered number of trees in the city of Rome. The preliminary results indicated that a proper utilization of biomass can constitute a valuable source of renewable energy, especially considering the hypothesis of an energy production plant fueled with biomass originated from a short supply chain [35-36].

The adopted MLR model, which utilizes four regressors, has given interesting results about the prediction of the gross time per tree. However, the limited number of observed yards prevents, so far, a generalized conclusion about this point. Therefore, future studies are required, also to individuate a model capable to effectively predict the cost. 
Author Contributions: The authors contributed equally to the work.

Funding: This research was funded by the Italian Ministry of Agriculture (MiPAAF) under the AGROENER project (D.D. n. 26329, 1st April 2016) - http://agroener.crea.gov.it/.

Acknowledgments: The authors are grateful to the following companies that carried out the works described in the paper: Ecologistica srl (Viterbo), Ecogeo srl (Roma), Ars Arborea sas (Guardea, TR), Il Giardino Malandrino srl (Roma), Verdeitalia srl (Roma).

Conflicts of Interest: The authors declare no conflict of interest.

\section{References}

1. Agrimi, M.; Ciancio O. Le Pin Pignon (Pinus pinea L.). Silva mediterranea 1984. Document provisoire monographie. FAO Ed. 116 pag.

2. Comune di Roma. Bilancio arboreo 2016. www.comune.roma.it. (accessed on 25/10/2020).

3. Massari, G. L'albero urbano a Roma. Ed. Tomo, 1991. 256 pp.

4. Yang, J. Assessing the Impact of Climate Change on Urban Tree Species Selection: A Case Study in Philadelphia. Journal of Forestry, 2009, 9, 364-372.

5. Burley, H.; Beaumont L.J.; Ossola A.; Baumgartner J.B.; Gallagher, R.; Laffan, S.; Esperon-Rodriguez, M.; Manea, A.; Leishman, M.R. Substantial Declines in Urban Tree Habitat Predicted under Climate Change. Science of The Total Environment, 2019, 685, 451-62. https://doi.org/10.1016/j.scitotenv.2019.05.287.

6. Costello, L.R.; Tso, J.; Jones, K.S. Structural failure profile: Italian stone pine (Pinus pinea). Western Arborist, 2015, 4, 44-47.

7. Gasperini, S.; Roatti, B.; Morelli, G. Analysis of anatomic structures of trees in relation to uprooting behaviour: the case study of Pinus pinea. 2016. Proceedings of: AFPP - 4e Conférence sur l'Entretien des Jardins, Espaces Végétalisés et Infrastructures, Toulouse - 19 and 20 October 2016, 142-149.

8. Garonna, A.; Foscari, A.; Russo, E.; Jesu, G.; Somma, S.; Cascone, P.; Guerrieri, E. The Spread of the NonNative Pine Tortoise Scale Toumeyella Parvicornis (Hemiptera: Coccidae) in Europe: A Major Threat to Pinus Pinea in Southern Italy. IForest - Biogeosciences and Forestry, 2018, 11, 628-34. https://doi.org/10.3832/ifor2864011.

9. Moricca, S.; Bracalini, M.; Croci, F.; Corsinovi, S.; Tiberi, R.; Ragazzi A.; Panzavolta, T. Biotic Factors Affecting Ecosystem Services in Urban and Peri-Urban Forests in Italy: The Role of Introduced and Impending Pathogens and Pests. Forests, 2018, 9, 2, 65. https://doi.org/10.3390/f9020065.

10. D'Amico, L.; Motta, E.; Annesi, T.; Scirè, M.; Luchi, N.; Hantula, J.; Korhonen, K.; Capretti, P. The North American P Group of Heterobasidion Annosum s.l. is Widely Distributed in Pinus Pinea Forests of the Western Coast of Central Italy. Forest Pathology, 2007 37, 5, 303-20. https://doi.org/10.1111/j.1439-0329.2007.00501.x.

11. Biocca, M.; Motta, E.; Lucatello, G.; Dallari, D. Aspects of the stability of the Italian Stone Pine (Pinus pinea L.) in Rome, Italy 2003. Proceedings of Second International Symposium on Plant Health in Urban Horticulture, Berlin, Germany, August 27-29. 228-229.

12. Gasparella, L.; Tomao, A.; Agrimi, M.; Corona, P.; Portoghesi, L.; Barbati A. Italian stone pine forests under Rome's siege: learning from the past to protect their future, Landscape Research, 2017, 42, 211-222, DOI: 10.1080/01426397.2016.1228862.

13. Biocca, M.; Bortolini, L. Macchine e tecniche per il verde urbano. Realizzazione, cura e manutenzione delle aree verdi. Consiglio per la ricerca in agricoltura e l'analisi dell'economia agraria - CREA (Ed.), Roma, Italy, 2019; 234 pp. ISBN 9788833850108.

14. Vogt, J.; Hauer, R. J.; and Fischer, B. C. The costs of maintaining and not maintaining the urban forest: a review of the urban forestry and arboriculture literature. Arboriculture E Urban Forestry 2015, 41, 293-323.

15. Morelli, G.; Raimbault, P.; Gasperini, S.; Roatti, B. Morfofisiologia, potatura e valutazione di stabilità / Morfophisiology, Pruning Techniques and Tree Assessment. Legami inscindibili. Acer 2017, 2, 25-32.

16. Mazzocchi, F.; Cecchini, M.; Monarca, D.; Colantoni, A.; Caruso, L.; Leopardi, F. An overview of risk assessment for tree climber arborists. Contemporary Engineering Sciences, 2015, 8, 1171 - 1177.

17. Bortolini, L.; Cividino, S. R. S.; Gubiani, R.; Cecchini, M.; Delfanti, L. M. P.; Colantoni, A. Urban green spaces activities: A preparatory groundwork for a safety management system. Journal of Safety Research, 2016, 56, 75-82. https://doi.org/10.1016/j.jsr.2015.12.004. 
18. Bagagiolo, G.; Laurendi, V.; Cavallo E. Safety Improvements on Wood Chippers Currently in Use: A Study on Feasibility in the Italian Context. Agriculture 2017, 7, 98; doi:10.3390/agriculture7120098.

19. Anderson, D. L.; Koomjian, W.; French, B.; Altenhoff, S. R.; Luce, J. Review of rope-based access methods for the forest canopy: safe and unsafe practices in published information sources and a summary of current methods. Methods in Ecology and Evolution 2015, 6, 865-872. https://doi.org/10.1111/2041-210X.12393.

20. Biocca, M.; Gallo, P.; Sperandio, G. Technical and Economic Evaluation of Urban Trees Pruning by Climbing Arborists. Lecture Notes in Civil Engineering 2020, 67, 653-660.

21. Colucci, M.; D'Antonio, P.; D'Antonio, C.; Evangelista, C. The biomasses deriving from the public parks management: an hypothesis of a city-wood-energy chain in Potenza. Proceedings of "International Conference Ragusa SHWA2010 - September 16-18, 2010 Ragusa Ibla Campus- Italy" 635-642.

22. Sperandio, G.; Fedrizzi, M.; Pagano, M.; Guerrieri, M.; Verani, S. Abbattimento di palme infestate da punteruolo rosso. Sherwood 2014, 204, 35-38.

23. Verani, S.; Sperandio, G.; Picchio, R.; Marchi, E.; Costa, C. Sustainability assessment of a self-consumption wood-energy chain on small scale for heat generation in central Italy. Energies 2015, 8, 5182-5197.

24. Li, Y.; Zhou, L.; W.; Wang, R. Z. Urban biomass and methods of estimating municipal biomass resources. Renewable and Sustainable Energy Reviews, 2017, 80, 1017-1030. https://doi.org/10.1016/j.rser.2017.05.214.

25. Raud, M.; Mitt, M.; Oja, T.; Olt, J.; Orupõld, K.; Kikas, T. The utilisation potential of urban greening waste: Tartu case study. Urban For. Urban Green. 2017, 21, 96-101. https://doi.org/10.1016/j.ufug.2016.11.014.

26. Velázquez-Martí, B.; Sajdak, M.; López-Cortés, I. Available residual biomass obtained from pruning Morus alba L. trees cultivated in urban forest. Renewable Energy 2013, 60, 27-33. https://doi.org/10.1016/j.renene.2013.04.001.

27. Spinelli, R.; Visser, R.J.M. Analyzing and Estimating Delays in Wood Chipping Operations. Biomass and Bioenergy, 2009, 33, 3, 429-33. https://doi.org/10.1016/j.biombioe.2008.08.003.

28. Olsen, E.D.; Kellogg, L.D. Comparison of Time-Study Techniques for Evaluating Logging Production. Transactions of the ASAE, 1983, 26, 6, 1665-68. https://doi.org/10.13031/2013.33821.

29. Tabacchi, G.; Di Cosmo, L.; Gasparini, P.; Morelli, S. Stima del volume e della fitomassa delle principali specie forestali italiane. Equazioni di previsione, tavole del volume e tavole della fitomassa arborea epigea. CRA, Unità di Ricerca per il Monitoraggio e la Pianificazione Forestale. Trento, Italy, 2011; 412 pp.

30. Miyata, E.S. Determining fixed and operating costs of logging equipment. General Technical Report NC-55. St. Paul, MN: Dept. of Agriculture, Forest Service, North Central Forest Experiment Station, MN, USA, 1980.

31. Olsen, E.D.; Hossain, M.; Miller, M. Statistical comparison of methods used in harvesting work studies. Research Contribution n. 23. Corvallis, OR: Oregon State University, Forest Research Laboratory; 1998. 31 pp.

32. IBM Corp. IBM SPSS Statistics for Windows, Version 24.0. Armonk, NY: IBM Corp. 2016.

33. R Core Team. R: a Language and Environment for Statistical Computing. R Foundation for Statistical Computing, 2013, Vienna, Austria. URL. www.R-project.org.

34. Nowak, David J., Miki Kuroda, e Daniel E. Crane. «Tree Mortality Rates and Tree Population Projections in Baltimore, Maryland, USA». Urban Forestry \& Urban Greening 2, n. 3 (gennaio 2004): 139-47. https://doi.org/10.1078/1618-8667-00030.

35. Khudyakova, G.I.; Danilova, D.A.; Khasanov, R.R. The Use of Urban Wood Waste as an Energy Resource. IOP Conference Series: Earth and Environmental Science, 72, 2017, 012026. https://doi.org/10.1088/17551315/72/1/012026.

36. Nowak, D.J.; Greenfield, E.J.; Ash, R.M. Annual Biomass Loss and Potential Value of Urban Tree Waste in the United States. Urban Forestry \& Urban Greening, 2019, 46, 126469. https://doi.org/10.1016/j.ufug.2019.126469. 